\title{
EPA significantly improves anti-EGFR targeted therapy by regulating miR-378 expression in colorectal cancer
}

\author{
WEN-HUI WENG ${ }^{1}$, WAI-HUNG LEUNG ${ }^{1,2}$, YEU JYE PANG ${ }^{3}$, LI-WEI KUO ${ }^{1}$ and HSI-HSIEN HSU ${ }^{2}$ \\ ${ }^{1}$ Department of Chemical Engineering and Biotechnology, Graduate Institute of Biochemical and Biomedical Engineering, \\ National Taipei University of Technology, Taipei $10608 ;{ }^{2}$ Division of Colorectal Surgery, Department of Surgery, \\ Mackay Memorial Hospital, Taipei 10491, Taiwan, R.O.C.; ${ }^{3}$ Department of Internal Medicine, \\ Queen Elizabeth The Queen Mother Hospital, Margate CT9 4AN, UK
}

Received December 8, 2017; Accepted June 26, 2018

DOI: $10.3892 / 01.2018 .9408$

\begin{abstract}
It is known that colorectal cancer (CRC) cells containing mutations of the genes KRAS and BRAF are predominate mechanisms causing resistance to epidermal growth factor receptor (EGFR) inhibitors, and commonly exhibit a lower expression of microRNA-378 (miR-378) when compared with the wild type. In the present study, the aim was to determine the possible mechanism which associates miR-378 with the mitogen-activated protein kinase pathway, and to determine the efficiency of eicosapentaenoic acid ethyl ester (EPA) in its ability to restore sensitivity towards cetuximab, an EGFR inhibitor. The results demonstrated that a combined treatment of $40 \mu \mathrm{M}$ EPA with $0.2 \mu \mathrm{M}$ cetuximab can significantly suppress the cell growth in KRAS-mutant and control wild-type cells. Furthermore, the higher phosphorylated protein level of extracellular-signal-regulated kinase 1/2 was notable in KRAS EPA-treated cells ( $\mathrm{P}=0.006-0.047)$ and resulted in significantly increased cell death; however, inconsistent results were indicated in EPA-treated BRAF-mutant cells, compared with the original cells (without treatment). KRAS-mutant and wild-type Caco-2 cells treated with EPA exhibited increased cetuximab response rates, but these response rates were reduced in the BRAF-mutant cells. In conclusion, upregulation of miR-378 induced by EPA may result in the significant restoration of sensitivity to cetuximab in the KRAS-mutant cells. The present data will contribute to a notable potential therapeutic solution for future clinical CRC treatments.
\end{abstract}

Correspondence to: Professor Wen-Hui Weng, Department of Chemical Engineering and Biotechnology, Graduate Institute of Biochemical and Biomedical Engineering, National Taipei University of Technology, 3 Zhongxiao East Road, Taipei 10608, Taiwan, R.O.C.

E-mail:wwhlab@gmail.com

Key words: colorectal cancer, eicosapentaenoic acid, anti-EGFR

\section{Introduction}

Lièvre et al (1) first disclosed colorectal cancer (CRC) with KRAS mutation as a predictor of poor response to anti-epidermal growth factor receptor (anti-EGFR) at 2006. The OPUS trial (2) in 2008 and the CRYSTAL trial (3) in 2009 reported KRAS mutations occured at a frequency of 42 and 36.5\% among metastatic CRCs. Those patients were insensitive to anti-EGFR therapy. Furthermore, BRAF mutations in CRCs were reported at a rate of $8.7 \%$ (4) and a $10 \%$ (5). The evidence identities that $\sim 50 \%$ of CRCs exhibit no response to anti-EGFR therapy, including cetuximab or panitumumab (1-11). KRAS mutations occur at an increased frequency, compared with BRAF mutations, and commonly occur at codon 12 (G12D) and 13 (G13D) of exon 2 in the KRAS gene (12-16); whereas, $90 \%$ of BRAF mutations occur in exon 15 (V600E) (17-19). According to previous studies, reduced expression of microRNA-378 (miR-378) may serve a crucial role in CRC, which is considered as an independent prognostic factor, and inhibits cell growth as well as invasion in tumor cells (20-23). It is known that miR-378 acts as an inhibitor in the mitogen-activated protein kinase (MAPK) pathway, which affect extracellular signal-regulated kinase (ERK) genes, such as ERK1/2; therefore, it is involved in cellular proliferation, differentiation, and transcription regulation and development (24). In our previous study, a reduced expression level of miR-378 was commonly observed in KRAS- or BRAF-mutant cells, compared with the wild-type CRC or normal control cells; however, following transfection of miR-378 into mutant CRC cells, to increase the expression level, it was observed that drug sensitivity to cetuximab was significantly restored and cell death was induced (25). The present data coincided with information from the databases TargetScanHuman (www.targetscan.org) and miRbase (www.mirbase.org), and further confirmed that miR-378 targets the 3'-untranslated region (UTR) of the ERK1/2 coding gene. Feng et al (26) also demonstrated that miR-378 suppressed the antigrowth protein transducer of Erb-B2 receptor tyrosine kinase, which serves as a transcriptional repressor of cyclin D1, a downstream effector of the human epidermal growth factor receptor 2-Ras-ERK pathway. The precursors of miR-378/378* are derived from the first intron of host gene peroxisome proliferator-activated 
receptor $\gamma$ coactivator $1 \beta$ (PGC-1 $\beta$ ) (27). Fatty acids can directly stimulate the gene PGC- $1 \beta$ expression, and as a result increase the co-expression of miR-378, which was demonstrated by our previous study (25).

Furthermore, a previous study indicated that PGC-1 $\beta$ serves a function in lipid metabolism, in which the genes coding mitochondrial fatty acid oxidation and oxidative phosphorylation were diminished in liver specific-PGC-1 $\beta$ knock out mice (28). A number of miR-378/378* target genes are associated with lipometabolism, including carnitine O-acetyltransferase, mediator complex subunit 13 and glucose transporter type 4 genes, and may also affect the development of lipogenesis in fatty cells $(27,29)$. Additionally, a number of studies demonstrated that fatty acids could significantly upregulate the expression of the PGC-1 $\beta$ gene, in order to affect the metabolism of mitochondrial biogenesis $(27,28,30)$.

EPA is one of omega-3 fatty acids commonly found in fish, including cod liver oil, salmons, herrings, sardines and various edible seaweeds. Based on a report by the European Food Safety Authority, a suggested dosage of intake for adults of EPA/docosahexaenoic acid (DHA) is 200 to $600 \mathrm{mg}$ per day, and 40 to $250 \mathrm{mg} /$ day for infants $>6$ months old, children and adolescents (31). Additionally, there are 0.2-1.2 mM free fatty acids in the human body $(32,33)$ which provided an estimate of the EPA concentration selection in current study. A number of studies demonstrated that EPA and DHA can trigger the majority of the activities of the caspase family members, including caspase- 8 , which are associated with proteases and cell apoptosis, which has been indicated in CRC and pancreatic cancer cells $(34,35)$. Notably, it has been observed that neoplastic oral keratinocyte cells are significantly suppressed by EPA through the inhibition of the expression of total protein ERK1/2, which increased the ERK1/2 phosphorylation (36). Based on our previous study, following restoring the expression level of miR-378, the CRC cells have a significant response to EGFR inhibitor cetuximab (25). In the present study, the aim was to firstly uncover the mechanism underlying the association between miR-378 and the MAPK pathway. Secondly, whether the gene expression of PGC-1 $\beta$ was also induced by EPA was investigated, with this gene indirectly increasing miR-378 co-expression and restoring cetuximab sensitivity. The results may directly benefit the treatment of patients with CRC containing KRAS or BRAF mutations.

\section{Materials and methods}

Cell lines and cell culture. The CRC cell lines included in the present study were SW480, HCT116, HT29, and Caco-2. SW480 and HCT116 contain KRAS mutations (G5571T and G5574A, respectively), HT29 contains a BRAF mutation (T171429A) and Caco-2 is a wild-type (without gene KRAS or BRAF mutations) CRC cell line, which was used as the internal control in the experiments, when required. All cell lines were cultured according to our previous study (25). In brief, the cells were cultured in high glucose Dulbecco's modified Eagle's medium (DMEM) containing $4 \mathrm{mM}$ glutamine, penicillin $(12.5 \mathrm{U} / \mathrm{ml})$, streptomycin $(6 \mu \mathrm{g} / \mathrm{ml}), 1 \mathrm{mM}$ sodium pyruvate and $10 \%$ fetal bovine serum (all from Gibco; Thermo Fisher Scientific, Inc., Waltham, MA, USA), then incubated at $37^{\circ} \mathrm{C}$ in an atmosphere containing $5 \% \mathrm{CO}_{2}$. SW480, HCT116,
HT29 and Caco-2 were selected in the present study due to them exhibiting aggressive growth, compared with other cell lines.

Supplements and reagents. Ultra-pure free fatty acid of EPA $(>99 \%)$ was purchased from Nu-Chek-Prep, Inc. (Elysian, MN, USA). The stock solution was diluted in $99 \%$ ethanol to a concentration of $1 \mathrm{mM}$ and aliquoted in dark-colored glass vials stored at $-20^{\circ} \mathrm{C}$ until used. EPA was added to DMEM to produce different testing concentrations from 0-40 $\mu \mathrm{M}(0,2$, $5,10,20,30$ and $40 \mu \mathrm{M})$, and was then used to treat the all cell lines for $24 \mathrm{~h}$. at $37^{\circ} \mathrm{C}$. The anti-EGFR cetuximab (Erbitux ${ }^{\circledR}$ ) was purchased from Merck KGaA (Darmstadt, Germany) and was added into the DMEM to produce final testing concentrations from $0-0.2 \mu \mathrm{M}(0,0.01,0.05,0.1$ and $0.2 \mu \mathrm{M})$, and then incubated with all cell lines at $37^{\circ} \mathrm{C}$ for $48 \mathrm{~h}$. The optimal EPA concentration was determined according to the $\mathrm{IC}_{50}$ calculation, for which growth inhibition was observed in half of the tested cells, and it was determined as $40 \mu \mathrm{M}$.

Reverse transcription-quantitative polymerase chain reaction $(R T-q P C R)$ assay. The primer sequences were as follows: MiR-378, 5'-CTCAACTGGTGTCGTGGAGT-3' and 5'-GGG ACTGGACTTGGAGTC-3' (37); RNU44, 5'-CCTGGATGA TGATAGCAAATGC-3' and 5'-GAGCTAATTAAGACCTT CATGTT-3' (38). The miR-378 expression levels in cells were detected prior to treatment, and then after $24 \mathrm{~h}$ treatment with $40 \mu \mathrm{M}$ EPA/DMEM. RNA extraction with MirVana ${ }^{\mathrm{TM}}$ miRNA Isolation kit (Ambion; Thermo Fisher Scientific, Inc.), An optical density of 260/280 $\mathrm{nm}$ absorbance ratio between 1.9-2.0 confirmed the quality of RNA (BioPhotometer plus; Eppendorf, Hamburg, Germany). TaqMan ${ }^{\circledR}$ MicroRNA Reverse Transcription kit (Applied Biosystems; Thermo Fisher Scientific, Inc.) was used to transcript RNA to cDNA-according to the manufacturer's protocols. In brief, the thermocycling conditions were: $5 \mathrm{~min}$ at $85^{\circ} \mathrm{C} ; 5 \mathrm{~min}$ at $60^{\circ} \mathrm{C}$; and lowered to $4^{\circ} \mathrm{C}$ which was immediately transferred to qPCR; or long term storage at $-20^{\circ} \mathrm{C}$. RT-qPCR of miR-378 was performed with the TaqMan Universal Master Mix II (no UNG) (Applied Biosystems; Thermo Fisher Scientific, Inc.) and TaqMan ${ }^{\circledR}$ MicroRNA Assays kit (Applied Biosystems; Thermo Fisher Scientific, Inc.) was used for qPCR. The thermocycling conditions were: $10 \mathrm{~min}$ at $95^{\circ} \mathrm{C}$ for the first stage; $15 \mathrm{sec}$ at $95^{\circ} \mathrm{C}$ for the second stage; and then $1 \mathrm{~min}$ at $60^{\circ} \mathrm{C}$; and total reaction for 40 cycles at $25^{\circ} \mathrm{C}$ for $30 \mathrm{sec}$. The relative expression levels of targeted genes in cells were calculated by normalizing with RNU-44 expression levels through the comparative Cq method (39). Finally, collected data were analyzed using the BioRad iCycle iQ system software, version 3.1 (Bio-Rad Laboratories, Inc., Hercules, CA, USA).

Comparing the cell viability efficiency using an MTS assay. All cell lines were grouped into four sets based on different treatments: Original cells treated with $1 \mathrm{X}$ PBS; cells treated with EPA only; cells treated with cetuximab only; and cells treated with EPA and cetuximab. CRC cells were firstly treated in gradient concentrations of $\operatorname{EPA}(0,2,5,10,20,30$, $40 \mu \mathrm{M}) / \mathrm{DMEM}$ mixtures, and incubated separately using a 96-microplate (BD Biosciences, Franklin Lakes, NJ, USA) at $37^{\circ} \mathrm{C}$ for $24 \mathrm{~h}$, followed by treating with grading concentrations 
of cetuximab $(0,0.01,0.05,0.1,0.20 \mu \mathrm{M})$ at $37^{\circ} \mathrm{C}$ for $48 \mathrm{~h}$. The cell viability was assessed using the CellTiter $96^{\circledR}$ AQueous One Solution Cell Proliferation Assay kit according to the manufacturer's protocols (Promega Corporation, Madison, WI, USA), and the absorbance was measured at $490 \mathrm{~nm}$.

ERK1/2 expression level and phosphorylation status detection by an ELISA assay. To observe the MAPK pathway, the expression level of key protein ERK1/2 was determined. Following all cell lines being treated with $40 \mu \mathrm{M}$ EPA at $37^{\circ} \mathrm{C}$ for $24 \mathrm{~h}$, ERK1/2 (Total/Phospho) InstantOne ${ }^{\mathrm{TM}}$ ELISA kit (cat. no. ABIN1981832; eBioscience; Thermo Fisher Scientific, Inc.), was used to detect total ERK $1 / 2$ protein expression and phosphorylation status (p-ERK1/2). In brief, the manufacturer's protocols of the ERK1/2 (Total/Phospho) InstantOne ELISA kit were followed with, and the absorbance was measured at $450 \mathrm{~nm}$ (Fig. 2).

Statistical analysis. SPSS 15.0 statistics software (SPSS, Inc., Chicago, IL, USA) was used for statistical analysis in the present study. Data are expressed as the mean \pm standard error of the mean and represent the fold differences among cells treated with EPA only, cells treated with cetuximab only and cells treated with EPA and cetuximab. Firstly, all three groups of cells were compared to their original cells, which were normalized at a base line of $100 \%$. Secondly, to understand the efficiency of cetuximab with/without EPA, EPA-treated cells were further normalized and used as a base line for comparison. Comparisons within each cell group was assessed by one-way analysis of variance. Individual comparisons among subgroups were analyzed with Tukey's post-hoc test. The miR-378, ERK1/2 protein and p-ERK1/2 expression levels prior to and following treatment with EPA were analyzed with Student's t test. $\mathrm{P}<0.05$ was considered to indicate a statistically significant difference.

\section{Results}

Efficiency of EPA on the viability of CRC cells viability. Different concentrations of EPA $(0,2,5,10,20,30$ and $40 \mu \mathrm{M})$ were produced by mixing with DMEM and used to treat all cells lines. The results demonstrated that Caco-2 and SW480 cells remained more stable when the EPA concentration increased, compared with HCT116 and HT-29 cells. The cell viabilities indicated a range between $95.9-111.5 \%$ and 98.0-112.0\%, respectively. The cell lines HCT116 and HT29 that were treated with $0-20 \mu \mathrm{M}$ EPA had cell viability ranges of 95.7-102.7\%, and 93.4-102.0\%, respectively; however, when the concentration increased to 30-40 $\mu \mathrm{M}$ EPA, the cell viabilities decreased to $71.9-53.3 \%$, and $81.3-79.0 \%$, respectively. Notably, cells treated with $40 \mu \mathrm{M}$ EPA had the greatest dosage response to cetuximab.

Efficiency of EPA on the expression of miR-378. Our previous data (24) demonstrated that mutant cells, either KRAS or BRAF, had significantly reduced expression of miR-378, compared with wild-type CRC cells; however, the present data indicated that the cells with an increased expression of miR-378 were notably associated with the addition of EPA, particularly at the concentration of $40 \mu \mathrm{M}$, with the exception of Caco-2 wild-type cells. The results indicated a significant increase in expression of miR-378 in the cells of SW480, HCT116 and HT29, with an increase by $0.98-(\mathrm{P}=0.005), 0.88$ $(\mathrm{P}=0.016)$ and 1.05 -fold $(\mathrm{P}=0.004)$, respectively, compared with their original control cells. Contrarily, miR-378 expression in wild-type Caco-2 cells did not demonstrate a significant difference to its original control cells ( $\mathrm{P}=0.317)$ (Fig. 1).

Cell ERK1/2 protein expression and p-ERK1/2 status following treatment with $40 \mu \mathrm{M}$ EPA. ERK1/2 protein expression and the p-ERK1/2 status were detected following all CRC cell lines being treated with $40 \mu \mathrm{M}$ EPA mixture for $24 \mathrm{~h}$. The results demonstrated that ERK1/2 protein expression was significantly decreased, compared with their original cells, except for BRAF-mutant HT29 cells. The KRAS-mutant CRC cells SW480 and HCT116 had a decreased ERK1/2 protein expression of $0.323-(\mathrm{P}=0.035)$ and 0.226 -fold $(\mathrm{P}=0.035)$, respectively. Furthermore, Caco-2 cells were also determined to have a decreased ERK $1 / 2$ protein expression of 0.484 -fold $(\mathrm{P}=0.022)$. Contrarily, a significant increase in $\mathrm{p}-\mathrm{ERK} 1 / 2$ was observed in all cell lines, except in HT29 cells (Fig. 2A). The expression of p-ERK1/2 in SW480, HCT116 and Caco-2 cells was increased by 1.61- $(\mathrm{P}=0.006), 1.32-(\mathrm{P}=0.047)$ and 4.96-fold ( $\mathrm{P}=0.033)$, respectively. Notably, a 0.42 -fold decrease in $\mathrm{p}$-ERK1/2 was determined in HT29 cells $(\mathrm{P}=0.029)$ (Fig. 2B).

Cetuximab effect on EPA-treated cells. Significant differences were observed in SW480 ( $\mathrm{P}=0.0217)$, HCT116 $(\mathrm{P}<0.001)$ and Caco-2 $(\mathrm{P}=0.0064)$ cell groups. With the exception of HT29 cells $(\mathrm{P}=0.1185)$, the cell viability of $\mathrm{CRC}$ cells treated with EPA and cetuximab were significantly decreased, compared with their controls. Furthermore, the combined EPA with cetuximab-treated cells were compared with cells treated with EPA only, in which all cell lines except HT29 cells were observed to have significantly decreased cell viability (Fig. 3; $\mathrm{P}<0.05)$. With cetuximab in a combination with EPA, the efficiency of cell growth inhibition was greater than when treated with cetuximab alone for the wild-type Caco-2 cells. Additionally, the response rate to cetuximab following treatment with 0.1 or $0.2 \mu \mathrm{M}$ cetuximab in the SW480, HCT116 and Caco-2 cells treated with $40 \mu \mathrm{M}$ EPA were significantly improved, compared with their controls $(\mathrm{P}=0.0062, \mathrm{P}=0.0176$ and $\mathrm{P}=0.0054$, respectively); however, the BRAF-mutant cell line HT29 $(\mathrm{P}=0.2116)$ remained insensitive to cetuximab following $40 \mu \mathrm{M}$ EPA treatment (Fig. 4).

\section{Discussion}

The crucial data of the present study indicated that $40 \mu \mathrm{M}$ EPA combined with $0.2 \mu \mathrm{M}$ cetuximab can significantly reduce the cell viabilities of KRAS-mutant CRC cell lines, with the exception of HT29 cells. Secondly, following treating cells with $40 \mu \mathrm{M}$ EPA, the cells exhibited significantly reduced the expression of protein ERK1/2 but increased the expression of phosphorylation ERK1/2 in KRAS-mutant CRC cells and also the wild-type CRC cells. Notably, contradicting data was observed in BRAF-mutant HT29 cells. Additionally, following treatment with EPA, the expression levels of miR-378 were 


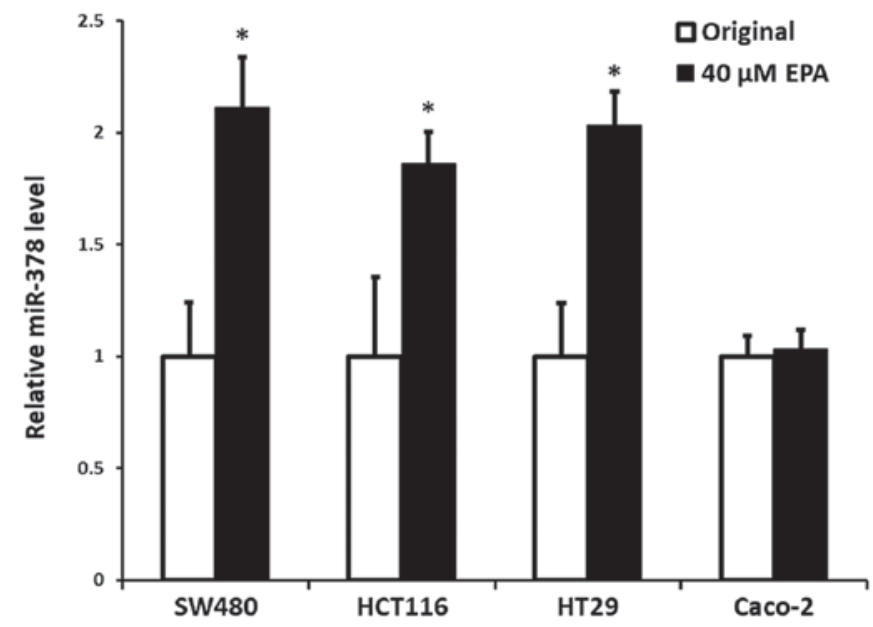

Figure 1. EPA induced the expression of miR-378 in CRC cells. All CRC cell lines were incubated in $40 \mu \mathrm{M}$ EPA culture medium for $24 \mathrm{~h}$ then compared with the untreated original cells. White bars represent the untreated original cells and the black bars represent EPA-treated cells. All the original cells were normalized to 1 then compared with the EPA-treated cells and displayed as relative miR-378 expression. All cell lines had a significantly increased expression of miR-378, with the exception of Caco-2 cells. Error bars represent standard errors, the $95 \%$ confidence interval. " $\mathrm{P}<0.05$ vs. original cells. EPA, eicosapentaenoic acid.

determined to be significantly increased in all cell lines, with the exception of wild-type Caco- 2 cells. These data were consistent with our previous study, in which the cells were treated with Lauric acid (25).

Based on the present results, the expression of miR-378 directly mediates the expression of ERK1/2, which is consistent to the TargetScanHuman database, where it is predicted that the 3 'UTR of mRNA ERK1/2 is one of the miR-378 target binding sites; therefore, this results in the inhibition of protein ERK1/2 expression $(24,26)$. However, the opposite results were determined for the ERK1/2 phosphorylation status, with the expression being increased in KRAS- and BRAF-mutant cells. Undetermined cellular mechanism may affect the MAPK signaling pathway, which may therefore trigger cell proliferation; nevertheless, the present results demonstrated a significant decrease in cell viabilities. Similar data has been reported by Nikolakopoulou et al (36), in which they produced a model regarding the reason why total protein ERK1/2 had the opposite expression level to the phosphorylation of ERK1/2. They concluded that EPA may be an important element to the EGFR ligand, and EPA may selectively inhibit the growth of premalignant and malignant keratinocytes by inducing a sustained activation of ERK1/2, but not have an effect on normal cells. Additionally, a number of studies also indicate that increased phosphorylation status of ERK1/2 is associated with cell death. For example, Yang et al (40) indicated that if the total protein expression level of ERK1/2 remained the same, the phosphorylation of ERK1/2 could still be increased, and consequently resulted in cell death. Similar data have been determined in CRC cells, lung cancer cells and cervical carcinoma studies, and this data agree that ERK1/2 phosphorylation could trigger the expression of caspase-3 and result in cell apoptosis (41-43). Although the potential mechanism is unknown between the ERK1/2 phosphorylation status and protein expression, which may be a result of unknown kinase effects. The MAPK/ERK
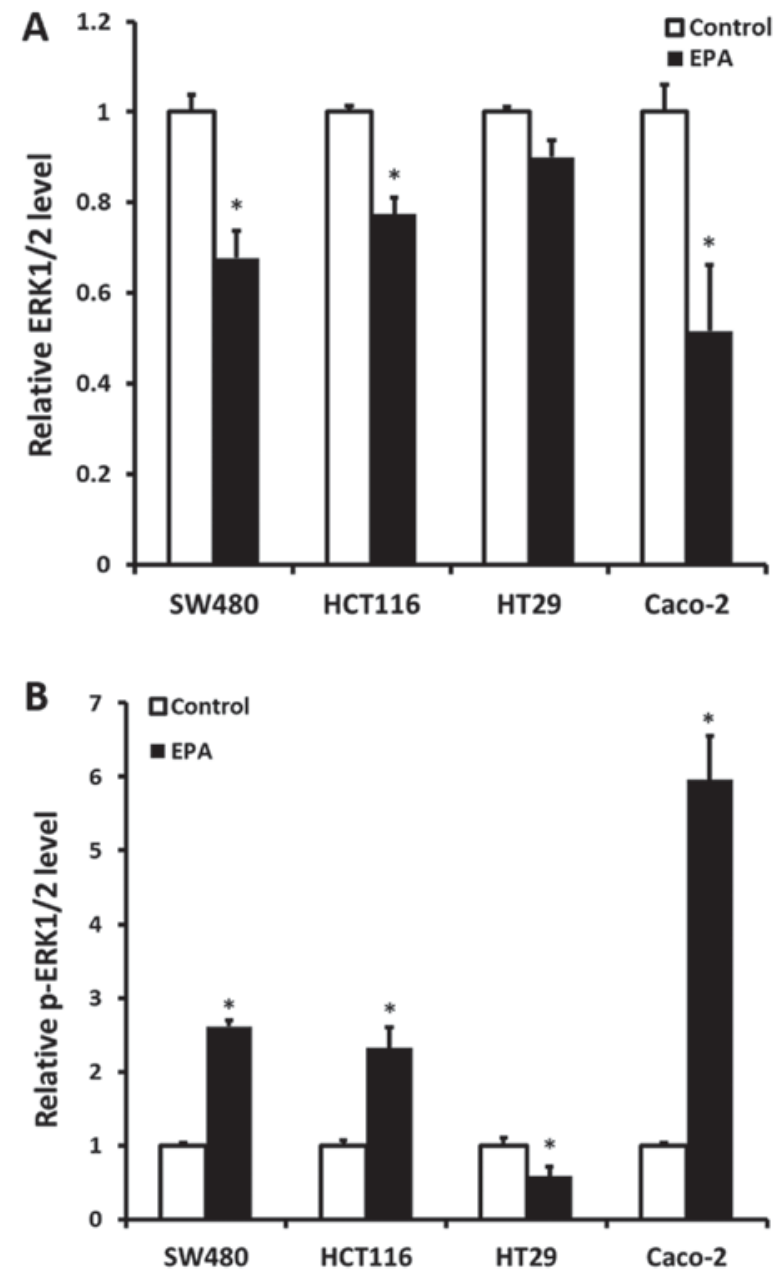

Figure 2. ERK1/2 protein and p-ERK between original cells and the cells cultured in $40 \mu \mathrm{M}$ EPA for $24 \mathrm{~h}$ were detected by an ELISA. (A) All cell lines exhibited significantly decreased ERK1/2 protein expression, with the exception of HT29 cells. (B) The p-ERK expression status was also determined simultaneously to ERK1/2. All cell lines exhibited significantly increased p-ERK expression, with the exception of HT29 cells, which exhibited the opposite data. White bars represent the untreated original cells; the black bars represent EPA-treated cells. Error bars represent standard errors, the $95 \%$ confidence interval. ${ }^{*} \mathrm{P}<0.05$ vs. original cells. EPA, eicosapentaenoic acid; ERK, extracellular signal-regulated kinase.

pathway with a high phosphorylation ERK expression is correlated with an increased rate of cell apoptosis, as demonstrated by a number of studies (40-44). The present study further clarified that EPA was associated with miR-378. Regardless of suppressed expression of ERK1/2, the activation of phosphorylation ERK1/2 still significantly inhibited cell growth.

There are at least two major pathways, phosphoinositide 3-kinase (PI3K) and MAPK pathways, that are involved in anti-EGFR therapy $(45,46)$. According to the present results, it was speculated the KRAS-mutant cells may be associated with the MAPK or PI3K/Akt pathways; therefore, miR-378 can trigger phosphorylation of ERK1/2 and result in cell apoptosis when the MAPK pathway is blocked or through an unknown mechanism of the PI3K/Akt pathway. This may explain the reason why the cells continued to survive following EPA treatment, but eventually succumbed to anti-EGFR cetuximab treatment; however, the BRAF-mutant cells exhibited a reduced expression level of phosphorylated ERK1/2, which is consistent to reduced 


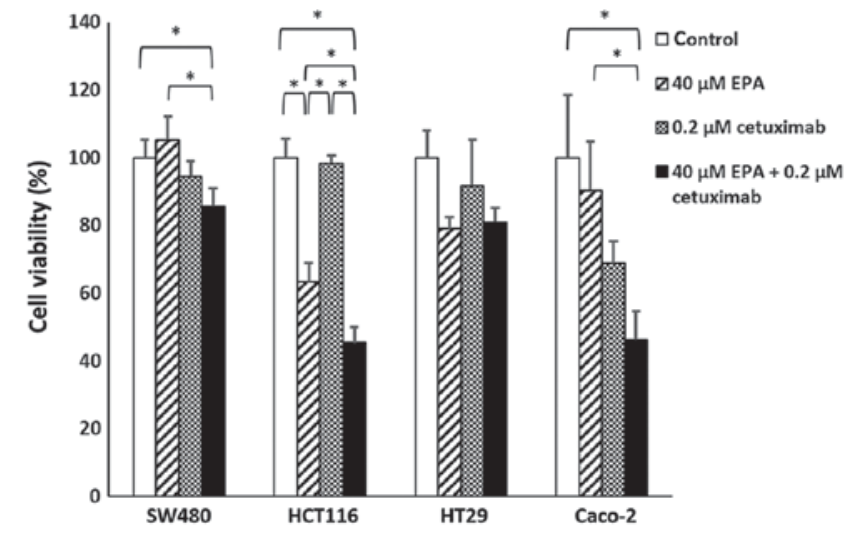

Figure 3. Comparison of the cell viability among the different group of cells. White bars represent original cell treated with 1X PBS. Oblique line bars represent cells treated with $40 \mu \mathrm{M}$ EPA. Meshed bar represent cells treated with $0.2 \mu \mathrm{M}$ cetuximab. Black bars represent cells treated with $40 \mu \mathrm{M}$ EPA $0.2 \mu \mathrm{M}$ cetuximab. Error bar represent standards error, the $95 \%$ confidence interval. $\mathrm{P}<0.05$. EPA, eicosapentaenoic acid.

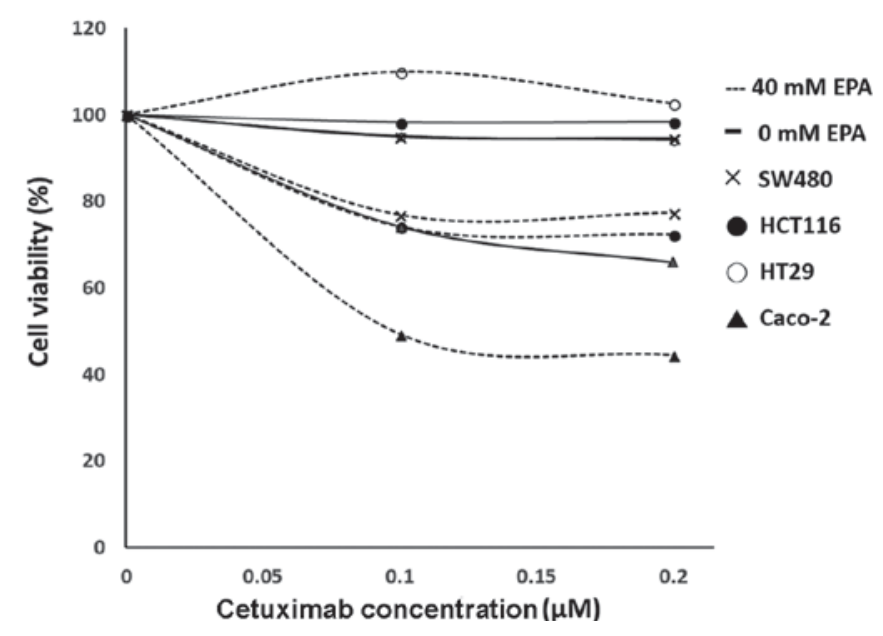

Figure 4. Efficiency of cetuximab test. Solid lines indicate cells without treatment with EPA. Dashed lines indicate cells treated with $40 \mu \mathrm{M}$ EPA Cross marks represent SW480 cells. Dark circles represent HCT116 cells. Hollow circles represent HT29 cells. Dark triangles represent Caco-2 cells. All the cells have been normalized to their control as $100 \%$ cell viability. The dashed lines below $100 \%$ indicate that the improvement of cell response to anti-EGFR antibodies was statistical significant. EPA, eicosapentaenoic acid.

ERK1/2 protein expression following restoration of miR-378 expression. Additionally, the BRAF-mutant HT29 cells exhibited no significant response to anti-EGFR antibody following the EPA treatment. We hypothesized that BRAF-mutant cells may harbor an unknown mechanism underlying cell signaling pathways, which differ from the KRAS-mutant cells that will require further research in the future.

To conclude, the present results indicated that EPA could significantly induce the expression level of miR-378 in CRC mutant cells, but not in the wide-type cells. Restoration of the anti-EGFR antibody sensitivity of the KRAS-mutant cells was achieved following treating the cells with up to $40 \mu \mathrm{M}$ of EPA, which was not observed in the BRAF-mutant cells in the present study. Notably, the status of phosphorylation of ERK1/2 may serve an important role in mediating the cell response to cetuximab therapy; however, the bio-mechanism behind this will require further study. This could also further reveal the discrepancy of clinical behaviors between KRAS- and BRAF-mutated colon cancer types.

\section{Acknowledgements}

The authors would like to thank Mr. Chi-Chia Pang from the Department of Chemical Engineering and Biotechnology, Graduate Institute of Biochemical and Biomedical Engineering, National Taipei University of Technology (Taipei, Taiwan) for editing.

\section{Funding}

The present study was supported by the National Taipei University of Technology, Mackay Memorial Hospital Joint Research Program (NTUT-MMH-107-03).

\section{Availability of data and materials}

The datasets used and/or analyzed in this study are available from the corresponding author on reasonable request.

\section{Authors' contributions}

WHW contributed to conception and design, acquisition of data, analysis and interpretation of data; and revising the article critically for important intellectual content; and giving final approval of the version to be published. WHL contributed to collecting samples, acquiring data and writing the article. YJP performed the experiments, and contributed to the acquisition of data and English editing. LWK performed the experiments and contributed to the acquisition of data. HHH contributed to the conception and design, and gave final approval of the version to be published.

\section{Ethics approval and consent to participate}

Not applicable.

\section{Patient consent to participate}

Not applicable.

\section{Competing interests}

The authors declare that they have no competing interests.

\section{References}

1. Lièvre A, Bachet JP, Le Corre D, Boige V, Landi B, Emile JF, Côté JF, Tomasic G, Penna C, Ducreux M, et al: KRAS mutation status is predictive of response to cetuximab therapy in colorectal cancer. Cancer Res 66: 3992-3995, 2006.

2. Bokemeyer C, Bondarenko I, Makhson A, Hartmann JT, Aparicio J, de Braud F, Donea S, Ludwig H, Schuch G, Stroh C, et al: Fluorouracil, leucovorin, and oxaliplatin with and without cetuximab in the first-line treatment of metastatic colorectal cancer. J Clin Oncol 27: 663-671, 2008.

3. Van Cutsem E, Köhne CH, Hitre E, Zaluski J, Chang Chien CR, Makhson A, D'Haens G, Pintér T, Lim R, Bodoky G, et al: Cetuximab and chemotherapy as initial treatment for metastatic colorectal cancer. NEJM 360: 1408-1417, 2009. 
4. Tol J, Nagtegaal ID and Punt CJ: BRAF mutation in metastatic colorectal cancer. NEJM 361: 98-99, 2009.

5. Di Nicolantonio F, Martini M, Molinari F, Sartore-Bianchi A, Arena S, Saletti P, De Dosso S, Mazzucchelli L, Frattini M, Siena $S$ and Bardelli A: Wild-type BRAF is required for response to panitumumab or cetuximab in metastatic colorectal cancer. J Clin Oncol 26: 5705-5712, 2008.

6. Baldus SE, Schaefer KL, Engers R, Hartleb D, Stoecklein NH and Gabbert HE: Prevalence and heterogeneity of KRAS, BRAF, and PIK3CA mutations in primary colorectal adenocarcinomas and their corresponding metastases. Clin Cancer Res 16: 790-799, 2010.

7. Di Fiore F, Blanchard F, Charbonnier F, Le Pessot F, Lamy A, Galais MP, Bastit L, Killian A, Sesboüé R, Tuech JJ, et al: Clinical relevance of KRAS mutation detection in metastatic colorectal cancer treated by Cetuximab plus chemotherapy. Br J Cancer 96: 1166-1169, 2007.

8. Frattini M, Saletti P, Romagnani E, Martin V, Molinari F, Ghisletta M, Camponovo A, Etienne LL, Cavalli F and Mazzucchelli L: PTEN loss of expression predicts cetuximab efficacy in metastatic colorectal cancer patients. Br J Cancer 97: 1139-1145, 2007.

9. Amado RG, Wolf M, Peeters M, Van Cutsem E, Siena S, Freeman DJ, Juan T, Sikorski R, Suggs S, Radinsky R, et al: Wild-type KRAS is required for panitumumab efficacy in patients with metastatic colorectal cancer. J Clin Oncol 26 1626-1634, 2008.

10. De Roock W, Piessevaux H, De Schutter J, Janssens M, De Hertogh G,Personeni N, Biesmans B, Van Laethem JL, Peeters M Humblet Y, et al: KRAS wild-type state predicts survival and is associated to early radiological response in metastatic colorectal cancer treated with cetuximab. Ann Oncol 19: 508-515, 2008.

11. Van Cutsem E, Köhne CH, Láng I, Folprecht G, Nowacki MP, Cascinu S, Shchepotin I, Maurel J, Cunningham D, Tejpar S, et al: Cetuximab plus irinotecan, fluorouracil, and leucovorin as first-line treatment for metastatic colorectal cancer: Updated analysis of overall survival according to tumor KRAS and BRAF mutation status. J Clin Oncol 29: 2011-2019, 2011.

12. Watzinger F, Mayr B, Haring E and Lion T: High sequence similarity within ras exons 1 and 2 in different mammalian species and phylogenetic divergence of the ras gene family. Mamm Genome 9: 214-219, 1998.

13. Andreyev HJ, Ross PJ, Cunningham D and Clarke PA: Antisense treatment directed against mutated Ki-ras in human colorectal adenocarcinoma. Gut 48: 230-237, 2001.

14. Bazan V,Migliavacca M,ZannaI, Tubiolo C, Grassi N,Latteri MA, La Farina M, Albanese I, Dardanoni G, Salerno S, et al: Specific codon $13 \mathrm{~K}$-ras mutations are predictive of clinical outcome in colorectal cancer patients, whereas codon $12 \mathrm{~K}$-ras mutations are associated with mucinous histotype. Ann Oncol 13: 1438-1446, 2002.

15. Benvenuti S, Sartore-Bianchi A, Di Nicolantonio F, Zanon C, Moroni M, Veronese S, Siena S and Bardelli A: Oncogenic activation of the RAS/RAF signaling pathway impairs the response of metastatic colorectal cancers to anti-epidermal growth factor receptor antibody therapies. Cancer Res 67: 2643-2648, 2007.

16. Esteller M, Gonzalez S, Risques RA, Marcuello E, Mangues R, Germà JR, Herman JG, Capellà G and Peinado MA: K-ras and p16 aberrations confer poor prognosis in human colorectal cancer. J Clin Oncol 19: 299-304, 2001.

17. Roskoski R Jr: RAF protein-serine/threonine kinases: Structure and regulation. Biochem Biophys Res Commun 399: 313-317, 2010.

18. Pakneshan S, Salajegheh A, Smith RA and Lam AK: Clinicopathological relevance of BRAF mutations in human cancer. Pathology 45: 346-356, 2013.

19. Deng G, Bell I, Crawley S, Gum J, Terdiman JP, Allen BA, Truta B, Sleisenger MH and Kim YS: BRAF mutation is frequently present in sporadic colorectal cancer with methylated hMLH1, but not in hereditary nonpolyposis colorectal cancer. Clin Cancer Res 10: 191-195, 2004.

20. Callari M, Dugo M, Musella V, Marchesi E, Chiorino G, Grand MM, Pierotti MA, Daidone MG, Canevari S and De Cecco L: Comparison of microarray platforms for measuring differential microRNA expression in paired normal/cancer colon tissues. PLoS One 7: e45105, 2012.

21. Faltejskova P, Svoboda M, Srutova K, Mlcochova J, Besse A, Nekvindova J, Radova L, Fabian P, Slaba K, Kiss I, et al: Identification and functional screening of microRNAs highly deregulated in colorectal cancer. J Cell Mol Med 16: 2655-2666, 2012 .
22. Mosakhani N, Sarhadi VK, Borze I, Karjalainen-Lindsberg ML, Sundström J, Ristamäki R, Osterlund $\mathrm{P}$ and Knuutila S: MicroRNA profiling differentiates colorectal cancer according to KRAS status. Genes Chromosomes Cancer 51: 1-9, 2012.

23. Wang YX, Zhang XY, Zhang BF, Yang CQ, Chen XM and Gao HJ: Initial study of microRNA expression profiles of colonic cancer without lymph node metastasis. J Dig Dis 11: 50-54, 2010.

24. Ganesan J, Ramanujam D, Sassi Y, Ahles A, Jentzsch C, Werfel S, Leierseder S, Loyer X, Giacca M, Zentilin L, et al: MiR-378 controls cardiac hypertrophy by combined repression of mitogen-activated protein kinase pathway factors. Circulation 127: 2097-2106, 2013.

25. Weng WH, Leung WH, Pang YJ and Hsu HH: Lauric acid can improve the sensitization of cetuximab in KRA/BRAF mutated colorectal cancer cells by retrivable microRNA-378 expression. Oncol Rep 35: 107-116, 2016.

26. Feng $\mathrm{M}$, Li Z, Aau M, Wong $\mathrm{CH}$, Yang $\mathrm{X}$ and $\mathrm{Yu} \mathrm{Q}$ : Myc/miR-378/TOB2/cyclin D1 functional module regulates oncogenic transformation. Oncogene 30: 2242-2251, 2011.

27. Carrer M, Liu N, Grueter CE, Williams AH, Frisard MI, Hulver MW, Bassel-Duby R and Olson EN: Control of mitochondrial metabolism and systemic energy homeostasis by microRNAs 378 and 378*. Proc Natl Acad Sci USA 109: 15330-15335, 2012.

28. Chambers KT, Chen Z, Crawford PA, Fu X, Burgess SC, Lai L, Leone TC, Kelly DP and Finck BN: Liver-specific PGC-1beta deficiency leads to impaired mitochondrial function and lipogenic response to fasting-refeeding. PLoS One 7: e52645, 2012.

29. Gerin I, Bommer GT, McCoin CS, Sousa KM, Krishnan V and MacDougald OA: Roles for miRNA-378/378* in adipocyte gene expression and lipogenesis. Am J Physiol Endocrinol Metab 299: E198-E206, 2010.

30. Crunkhorn S, Dearie F, Mantzoros C, Gami H, da Silva WS, Espinoza D, Faucette R, Barry K, Bianco AC and Patti ME: Peroxisome proliferator activator receptor gamma coactivator-1 expression is reduced in obesity: Potential pathogenic role of saturated fatty acids and p38 mitogen-activated protein kinase activation. J Biol Chem 282: 15439-15450, 2007.

31. EFSA: Scientific option on the tolerable upper intake level of eicosapentaenoic acid (EPA), docosahexaenoic acid (DHA) and docosapentaenoic acid (EPA). European Food Safety Authority Journal 10: 2815, 2012.

32. Ijzerman RG, Stehouwer CD, Serné EH, Voordouw JJ, Smulders YM, Delemarre-van de Waal HA and van Weissenbruch MM: Incorporation of the fasting free fatty acid concentration into quantitative insulin sensitivity check index improves its association with insulin sensitivity in adults, but not in children. Eur J Endocrinol 160: 59-64, 2009.

33. Mensink RP, Zock PL, Kester AD and Katan MB: Effects of dietary fatty acids and carbohydrates on the ratio of serum total to HDL cholesterol and on serum lipids and apolipoproteins: A meta-analysis of 60 controlled trials. Am J Clin Nutr 77: 1146-1155, 2003

34. Giros A, Grzybowski M, Sohn VR, Pons E, Fernandez-Morales J, Xicola RM, Sethi P, Grzybowski J, Goel A, Boland CR, Gassull MA and Llor X, et al: Regulation of colorectal cancer cell apoptosis by the n-3 polyunsaturated fatty acids Docosahexaenoic and Eicosapentaenoic. Cancer Prev Res (Phila) 2: 732-742, 2009.

35. Fukui M, Kang KS, Okada K and Zhu BT: EPA, an omega-3 fatty acid, induces apoptosis in human pancreatic cancer cells: Role of ROS accumulation, caspase- 8 activation, and autophagy induction. J Cell Biochem 114: 192-203, 2013.

36. Nikolakopoulou Z, Nteliopoulos G, Michael-Titus AT and Parkinson EK: Omega-3 polyunsaturated fatty acids selectively inhibit growth in neoplastic oral keratinocytes by differentially activating ERK1/2. Carcinogenesis 34: 2716-2725, 2013.

37. Ding N, Sun X, Wang T, Huang L, Wen J and Zhou Y: miR-378a-3p exerts tumor suppressive function on the tumorigenesis of esophageal squamous cell carcinoma by targeting Rab10. Int J Mol Med 42: 381-391, 2018.

38. Bai B, Liu H and Laiho M: Small RNA expression and deep sequencing analyses of the nucleolus reveal the presence of nucleolus-associated microRNAs. FEBS Open Bio 4: 441-449, 2014.

39. Livak KJ and Schmittgen TD.: Analysis of relative gene expression data using real-time quantitative PCR and the 2(-delta delta C(T)) method. Methods 25: 402-408, 2001.

40. Yang L, Su T, Lv D, Xie F, Liu W, Cao J, Sheikh IA, Qin X, Li L and Chen L: ERK1/2 mediates lung adenocarcinoma cell proliferation and autophagy induced by apelin-13. Acta Biochmm Biophys Sin (Shanghai) 46: 100-111, 2014. 
41. Randhawa H, Kibble K, Zeng H, Moyer MP and Reindl KM: Activation of ERK signaling and induction of colon cancer cell death by piperlongumine. Toxicol In Vitro 27: 1626-1633, 2013.

42. Liu Y, Yang Y, Ye YC, Shi QF, Chai K, Tashiro S, Onodera S and Ikejima T: Activation of ERK-p53 and ERK-mediated phosphorylation of Bcl-2 are involved in autophagic cell death induced by the c-Met inhibitor SU11274 in human lung cancer A549 cells. J Pharmacol Sci 118: 423-432, 2012.

43. Singh S, Upadhyay AK, Ajay AK and Bhat MK: p53 regulates ERK activation in carboplatin induced apoptosis in cervical carcinoma: A novel target of p53 in apoptosis. FEBS Lett 581: 289-295, 2007.

44. Schweyer S, Soruri A, Meschter O, Heintze A, Zschunke F, Miosge N, Thelen P, Schlott T, Radzun HJ and Fayyazi A: Cisplatin-induced apoptosis in human malignant testicular germ cell lines depends on MEK/ERK activation. Br J Cancer 91: 589-598, 2004.
45. Liu W, Ren H, Ren J, Yin T, Hu B, Xie S, Dai Y, Wu W, Xiao Z, Yang $X$ and $X$ ie D: The role of EGFR/PI3K/Akt/cyclinD1 signaling pathway in acquired middle ear cholesteatoma. Mediators Inflamm 2013: 651207, 2013.

46. Lo HW and Hung MC: Nuclear EGFR signalling network in cancers: Linking EGFR pathway to cell cycle progression, nitric oxide pathway and patient survival. Br J Cancer 94: 184-188, 2006. 